\title{
ISSUES IN TRANSLATION OF BALINESE CULTURAL TERMS INTO ENGLISH
}

\author{
Kadek Putri Yamayanti \\ Linguistic Program in Translation Studies, Faculty of Arts, Udayana University, Indonesia \\ Email: pyamayanti@gmail.com
}

APA Citation: Yamayanti, K. P. (2020). Issues in translation of Balinese cultural terms into English. Indonesian EFL Journal, 6(1), 63-72. doi: 10.25134/ieflj.v6i1.2639.

\begin{abstract}
This descriptive qualitative study investigates translation equivalent of Balinese cultural terms into English. It is based on the understanding that cultural terms belong to salient part in dealing with translation due to the cultural gap between source and target languages. Therefore, this study is conducted in order to find out the degree of equivalence between Balinese cultural terms and their translations into English in the book entitled Memahami Roh Bali 'Desa Adat sebagai Ikon Tri Hita Karana' and its translation in Discovering the Spirit of Bali 'Customary Village as Icon of Tri Hita Karana'. In finding the degree of equivalence, componential analysis especially the binary features was applied in terms of confirming the semantic features. The result showed that all translated cultural terms have no exact synonymy into source language. Some semantic features do not occur in target language as a result of lack terms in target language. The translator tends to replace cultural terms in source language into appropriate terms in target language based on his knowledge and experiences even in some cases, it shows the loss and gain information. However, overall, those translated cultural terms still can share some basic semantic features of the source language.
\end{abstract}

Keywords: cultural term; semantic features; equivalence.

\section{INTRODUCTION}

Translation is an art of transferring meaning of one language to other languages. It becomes an art since there is a process of creativity and imagination involved while translating. The translator needs to "picture" the meanings of source language and then "paints" those meanings in different "picture" which is acceptable in target language. The process of figuring out the meaning can be stated as the process of making imagination in interpreting the meaning. Eventually, it continues to the process of creativity in making form in target language which carries the appropriate meaning as in source language. In depth, as stated by Larson (1998, p. 3), "translation consists of transferring the meaning of the source language into the receptor language. Only the form changes." In translating a text, the focus of the translator, certainly is not to the form of source language (SL) and target language (TL), but to the meaning. As the meaning carries out all the gist of the text, in translating the meaning of SL, it should be replaced as equivalent as in the TL.

The issue on how to deal with the equivalence in translation is quite salient in translation field. Referring to the theory of objectivity claimed by Rand (1966), it settles with the translation possibility. It argues that translation becomes possible since there is a concept which conveys the same reality that is named as a referent. Moreover, Cohen (1985) agrees with conceptual equivalent makes translatability possible. When the conceptual meaning finds its equivalent in the $\mathrm{TL}$, it means the function of translation is fulfilled. However, Cohen's statement arises bias in the referent of abstract object or even real referent which does not exist in other languages, for instance the words which refer to culture.

The referent of a word that has no real object in one language can be easily found in the book which contains a lot of cultural terms. The instance can be found in the book entitled Memahami Roh Bali 'Desa Adat sebagai Ikon Tri Hita Karana' and its translation in Discovering the Spirit of Bali 'Customary Village as Icon of Tri Hita Karana'. Some cultural terms are found in this book since the book theme is to reveal the cultural of Bali. The translator faces difficulty in order to pick up the closest term presenting the meaning of SL into TL. Yet, finding out the semantic meaning of SL and TL through componential analysis becomes one of intermediary to figure out the equivalence of the translation and it can solve the difficulty found by translator. Componential analysis especially in term of semantic meaning analysis is the "most accurate translation procedure... which highlights 
the message" (Newmark, 1988, p. 114). Componential analysis refers to the description of the meaning of words through structured sets of semantic features, which are given as "present $(+)$ ", "absent (-)" or "indifferent with reference to feature $( \pm)$ ". By applying componential analysis, we can evaluate explicitly the semantic features both SL and TL. The comparing of those semantic features is clearly enough in order to show the similarities and differences carried by SL and TL as well. One-to-one correspondence guides us in order to figure out to what degree of equivalence in SL and TL obtained.

There are several studies conducted in this field. Hapsari and Setyaningsih (2013), for instance, had conducted research on analysing types of cultural words in the English version of Twilight novel. Another relevant study focused on the translation of cultural terms in English version of Laskar Pelangi novel. This study investigated the translation quality of those cultural terms as well (Kuncara, 2015). Yet, this study has slightly different from the present study since the present study showed up the translation equivalence by componential analysis. Further, another study tried to analyze the cultural term and procedure of translation in translating cultural terms that found in Bali Travel News (Wirayanti, Erfiani \& Agustia, 2018). The difference of this study and the present study is that the present study focused merely on Balinese cultural terms. In addition, Saraswati (2014) analyzed translation strategies in translating Balinese cultural terms into English. However, she did not concern on the translation equivalence especially in term of semantic aspect.

Those studies provided the translation of cultural terms. Yet, some of them took different scope of data. The present study presented the analysis of translation of Balinese cultural terms which emphasized the analysis of translation equivalence. The translation equivalence was conducted by providing semantic features analysis through componential analysis of source and target languages. Therefore, it can be stated that the present study focused on classifying Balinese cultural terms into some categories and finding out the degree of equivalence of Balinese cultural terms and their translations into English through componential analysis.

\section{METHOD}

The descriptive qualitative method was applied in order to conduct full description of the data analyses. The data were gained through intensive reading the SL book "Memahami Roh Bali 'Desa Adat sebagai Ikon Tri Hita Karana" and its translation "Discovering the Spirit of Bali 'Customary Village as Icon of Tri Hita Karana"'. Note taking technique was applied in finding the Balinese cultural terms in SL and their translations. Meanwhile, comparative technique is applied in comparing the data through its semantic features by componential analysis proposed by Newark (1988). The analysis was conducted in some steps. First, the selected data, Balinese cultural terms, were classified into cultural category proposed by Newmark (1988). Then, cultural terms in SL and TL were compared descriptively in concert to look for the equivalence of SL and TL through its semantic features in componential analysis.

\section{RESULTS AND DISCUSSION}

The Balinese cultural terms found in the book Memahami Roh Bali 'Desa Adat sebagai Ikon Tri Hita Karana' and its translation in Discovering the Spirit of Bali 'Customary Village as Icon of Tri Hita Karana' belong to some categorization based on Newmark's theory. Those Balinese cultural terms are (1) Ecology, (2) Material Culture, (3) Organization, Customs, Activities, Procedures and Concepts, and (4) Social Culture. The analysed data are presented in the form of phrase and table.

\section{Ecology}

The term of Balinese culture found related into ecology is bungkak or klungah. As stated in Oxford Advanced Learner's Dictionary that ecology is the relation of plants and living creature to each other and to their environment. This definition is in line with the theory proposed by Newmark (1988) which stated that cultural categories especially ecology includes flora, fauna and weather. Bungkak or klungah is the name of young coconut in Bali. Actually, there is a bit difference between bungkak and klungah. In Bali, we have different name for each stage of coconut fruit. First, there is bungsil which refers to the very early stage of coconut fruit. Then, when the fruit grows a bit, it is called as klungah. The inside shell of klungah can be eaten as part of lawar, Balinese traditional food. Continuously, klungah grows up into bungkak. Bungkak has its own position in Balinese Hinduism. In this stage, this coconut fruit has many functions related into religious offering. Balinese Hinduisms believe that the water (juice) of this coconut can purify our mind and soul by drinking it after offered to 
the God or after it is sparkle into our body especially on the head. The next stage is called kuud which refers to late young coconut. It is usually used for making ice in Indonesia. Last, it is nyuh. This is the common coconut fruit we find in supermarket. It can be stated as the old coconut fruit.

SL: ... dan abunya dimasukkan ke dalam bungkak atau klungah dan ... (p.46)

TL: ... and their ashes put into young yellowish coconut fruit and... (p.106)
As the data shows, the word bungkak or klungah is translated into one term young yellowish coconut fruit. The translator tends to translated it by using phrase. Young yellowish coconut fruit may have the appropriate equivalent into SL. As the English has no different name of each stage in coconut fruit, this phrase is enough in order to present the gist of SL into TL. The comparing of semantic features can be seen on the table 1 .

Table 1. Bungkak atau klungah and young yellowish coconut fruit

\begin{tabular}{lcc}
\hline \multicolumn{1}{c}{ Semantic Features } & SL & TL \\
\cline { 2 - 3 } & Bungkak atau Klungah & Young Yellowish Coconut Fruit \\
\hline Inanimate/thing & + & + \\
Coconut fruit & + & + \\
Yellowish colour & $+/-$ & + \\
It has Balinese Hinduism religion function & + & - \\
\hline
\end{tabular}

The table shows that bungkak or klungah has some colours, such as yellowish and greenish. This semantic feature belongs to one miss in TL. In TL, the translator directly declares that the colour of bungkak or klungah is yellowish. Meanwhile, in fact, it has another colour, greenish. However, this may occur as the translator has knowledge that the yellowish one is common used in religious activity rather than the greenish.

\section{Material culture: Food, housing and city}

The terms of material culture refer to the custom materials used in a society. It is according to the Newmark's (1988) categorization on culture which implies material culture as food and beverage, clothes, housing and transportation and the others. In this occasion, the Balinese cultural terms found are lawar, sate and pura. The following explanation presents semantic features of those culture terms and their translations.

The first data is material culture related to food. That is lawar and its translation chopped meat.

SL: Dagingnya selanjutnya digunakan untuk membuat makanan sesajen seperti misalnya lawar dan sate. (p.43)
TL: The meat is then used to make sesaji foods such as chopped meat and satay. (p.104)

The word lawar belongs to cultural terms related to material culture especially food. Lawar is one of Balinese cultural foods which is served not only for meal but also, for Balinese Hinduism, it is one of offering to the God. There are many kinds of lawar which depend on the main protein ingredient, such as lawar with chicken called lawar ayam, lawar mixed with pork called pork lawar and lawar mixed with fresh or raw blood called lawar barak as the colour is red. However, sometimes the type of lawar is different from one regency to others, for instance in Gianyar regency. In this regency, lawar is made by mixing the shell of young coconut, klungah and long bean as the vegetables with meat and others common (Balinese) ingredients.

The word lawar is translated into chopped meat in English. The phrase chopped meat cannot be stated as equivalent as the meaning of lawar in SL. Chopped meat refers to the meat which is cut into pieces by sharp knife. The semantic features can be shown as follow:

Table 2. Lawar and chopped meat

\begin{tabular}{lcc}
\hline \multicolumn{1}{c}{ Semantic Features } & SL & TL \\
\cline { 2 - 3 } & Lawar & Chopped Meat \\
\hline Inanimate/thing & + & + \\
Type of food & + & + \\
Ingredients: & & + \\
Meat & + & - \\
Vegetables mainly jackfruit and & + & + \\
\hline
\end{tabular}




\begin{tabular}{lll}
\hline fresh grated coconut & & \\
Fresh or raw blood & + & - \\
A lot of spices & + & - \\
\hline
\end{tabular}

From the table, it can be seen that TL has represented some basic features of SL. Those are as one kind of food made by main ingredient, meat. If it is seen from Newmark's (1988) definition in translation "the basic process of componential analysis is to compare a SL word with a TL which has a similar meaning, but is not an obvious one-to-one equivalent, by demonstrating first their common and then their differing sense components", the translator has demonstrated prior to the common component of SL into TL. However, there are some features which do not occur in the TL. It can be pointed out that chopped meat has no semantic features of ingredients especially in representing the jackfruit and/or fresh grated coconut as the vegetable mixed with the meat. The existence of fresh or raw blood in lawar as well as made it quite different with chopped meat. Lawar is commonly mixed with fresh or raw blood to increase its taste. Whereas, chopped meat merely refers to pale meat without any combination of ingredients. Therefore, the translation of lawar into chopped meat can be stated not as equivalent as the gist of
SL. The translator needs to add more explication of certain chopped meat to conduct clear understating of what lawar is in English.

The next cultural term related into material culture especially food is sate. Sate which is translated into satay basically has obtained equivalent in translation. It is because the term only has slightly differences between SL and TL. The data is stated below:

SL: Dagingnya selanjutnya digunakan untuk membuat makanan sesajen seperti misalnya lawar dan sate. (p.43)

TL: The meat is then used to make sesaji foods such as chopped meat and satay. (p.104)

The translation of a single term sate into a single term satay as well can be justified. The word satay has reference to a meat cooked on stick and served with a sauce made with peanuts based on Oxford Advanced Learner's Dictionary. Even the term in SL and TL share the basic semantic feature as a meat cooked on stick, there are some miss features such as on the ingredients. The binary features is shown below:

Table 3. Sate and satay

\begin{tabular}{lcc}
\hline \multicolumn{1}{c}{ Semantic Features } & SL & TL \\
\cline { 2 - 3 } & Sate & Satay \\
\hline Inanimate/thing & + & + \\
Type of food & + & + \\
Ingredients: & & \\
Meat & + & + \\
Grated coconut & + & - \\
Palm sugar & + & + \\
Peanuts sauce & - & - \\
The way it is served: & + & \\
Wrapped around the bamboo & & \\
\hline
\end{tabular}

As it can be seen on the table, the main ingredients of sate, besides meat, are grated coconut and palm sugar. Balinese usually make their sate by adding palm sugar as the flavouring and grated coconut. In addition, sate in Balinese has no peanuts sauce. The prominent difference of sate and satay is the way it served. Common satay is served by sticking the meat on skewer. Conversely, sate is served by wrapping the chopped meat mixed some ingredients around the bamboo. Yet, the translation reaches its equivalent and it can be justified.
Moreover, the material culture discussed is related into housing and city. The example of the use of the data is as follow:

SL: Pengecualian dibuat dalam hal lahan (lahan kering atau lahan basah) yang dimiliki oleh pura. (p.18)

TL: An exception was made in the case of land (dry and wet land) owned by the temple (p.82)

From the data, it can be analysed that the word pura can be categorized into cultural term related into material cultural since it refers to the place or object made by human in specific complex shrines which has their specific function and authority. The word pura which is translated into temple is a common case. It is because 
almost all people know that temple is a place of Hinduism to doing worship to God. However, there is certain feature gained in TL, temple. The word temple represents as the building which is not only for Hinduism, but also for other religions such as Buddhist to pray. Although it has additional information in TL which can lead the readers into misunderstanding, the translator have considered it since the context of the text is in
Bali where mostly Balinese Hinduism live. This is in line with Newmark's (1988) definition in translation which stated that there is no one-toone equivalent translation but first by demonstrating the common sense of SL and it is followed by differencing sense component. Therefore, the translation of pura into temple can reach translation equivalent.

Table 4. Pura and temple

\begin{tabular}{lcc}
\hline \multicolumn{1}{c}{ Semantic Features } & SL & TL \\
\hline Inanimate/thing & Pura & Temple \\
A place for praying & + & + \\
For the Balinese Hinduism People & + & + \\
It consists of shrine that have their own function & + & $+/-$ \\
It has deposit to maintain its need & + & - \\
\hline
\end{tabular}

According to the semantic features represented above, there is also one feature which makes the difference between pura and temple. That is the authority of pura. In Bali, pura is organized specifically by its society. Therefore, in some conditions, pura can have its own deposit to maintain its needs. The deposit is usually in the form of land. The land will be rented and the money is used for supporting every temple's need, such as renovation, etc. In English culture, there is rarely or no kind of authority had by the temple.

\section{Organization, customs, activities, procedures and concepts}

There are many cultural terms related to organization, customs, activities, procedures and concepts found in the data. The first one will be discussed is related to religious thing.

The data below belongs to religious cultural terms. Tirta panglukatan is translated into holy water for cleansing. The data is represented in sentence below:

SL: Yang kedua, Sugihan Bali dirayakan dengan melaksanakan ritual dan memohon tirta panglukatan, ... (p.42)
TL: Second, Sugihan Bali is celebrated by holding a ritual and asking for holy water for cleansing ... (p.103)

From the data, it can be analyzed that the word tirta can be categorized into cultural term related with religion based on Newmark (1988) because the word tirta is a term which refers to holly water in Balinese Hinduism. However, in this case, the word tirta occurs with additional phrase, panglukatan. Tirta is water which has been given mantra. Then, it is believed to give blessing to us. In some cases, tirta has different functions. There are many kinds of tirta in Bali. Those are tirta prayascita, tirta durmanggala, tirta pengentas, tirta penembak, etc. Those tirta have their function and so does tirta panglukatan.

Tirta panglukatan is holy water which is the combination between water and many kinds of flowers given mantra. As one kinds of holy water, tirta panglukatan has function to purify our mind and soul. It is not like common water which cleaning our body from dust or dirt, but Balinese Hinduisms believe that it also cleans or purifies our mind after we drink it or after it is sprinkle to our body especially into head.

Table 5. Tirta Panglukatan and holy water for cleansing

\begin{tabular}{lcc}
\hline \multicolumn{1}{c}{ Semantic Features } & SL & TL \\
\hline Inanimate/thing & Tirta Panglukatan & Holy Water for Cleansing \\
Made from water and flower which is & + & + \\
given mantra & + & - \\
It has Hinduism religion function & & - \\
Used for cleaning mind and soul & + & - \\
\hline
\end{tabular}

Tirta panglukatan is translated into holy water for cleansing. The phrase in TL reaches the closet equivalent to SL. As it can be seen on the table, some semantic features depicted in SL are 
not represented in TL. However, even there are miss semantic features in translation which leading to loss information in TL, the meaning can be clearly understood by the readers in TL by considering the context. The cultural information may lose in this translation, but the main essence as the holy water for cleansing still can be obtained. It can be drawn that translator has similar understanding with Newmark's (1988) notion on translation where the basic process of translation.

The next data discussed is still in religious term specifically in the activity or event. The data presented is one of the events related into religious cultural of Balinese. Piodalan is ceremony done in every temple in Bali. This ceremony takes every six or twelve months according to the Balinese calendar. Offering things always come in this ceremony as well such as fruits and some offerings made by coconut leaves arranged with flowers. If it is compared 'roughly' to English, piodalan is like anniversary componential analysis is not obviously one-to-one

of the temple. It shows the time of the temple inauguration counting in Balinese calendar. In this event, there will be a Balinese priest who leads the ceremony.

SL: Penduduk desa secara kolektif atau bersama-sama bertanggung jawab atas penyelenggaraaan semua jenis upacara, seperti piodalan. (p.19)

TL: The villagers are collectively responsible for the organization of all kinds of upacara, such as the yearly temple festival. (p.83)

In this occasion, the translator translates the word piodalan into noun phrase yearly temple festival. The occurrence of the word yearly conducts perspective to the readers that the event is done once a year, like Christmas. In fact, this event is done every six or twelve months according to Balinese calendar. Balinese calendar has different amount of day in one month. One month in Balinese calendar consists of 35 days in common calendar's day. Therefore, the time takes in TL miss in term of the amount of the days.

Table 6. Piodalan and yearly temple festival

\begin{tabular}{lcc}
\hline \multicolumn{1}{c}{ Semantic Features } & SL & TL \\
\hline Event & Piodalan & Yearly Temple Festival \\
Done by Balinese Hinduism people & + & + \\
Done with typically Balinese Hinduism offerings & + & - \\
It consists of Hinduism symbolization & + & - \\
Done according on the Balinese calendar & + & - \\
\hline
\end{tabular}

From the table, it can be seen that there is only one common sense of SL and TL which shares the same semantic feature. Yet, in this case, it still can be considered as the translator has determined first common sense of semantic features which is in line with Newmark's (1988) notion.

Then, there are some cultural concepts found in the data. The first one is related to colour. Those colours are brumbun and putih siyungan. The concept of colour can diverge into one language to others. Brumbun is concept of colour which refers to the composite of main colours in Balinese Hinduisms belief. Those colours are red, black, yellow and white. The appearance of the data is as follow:

SL: ... menggunakan lima ekor ayam dengan warna bulu yang berbeda, yaitu hitam, putih, merah jambu, brumbun, dan putih siyungan. (p.45)

TL: ... employs five chickens of different colours, namely black, white, crimson, multicolours and whitish black. (p.109)

Table 7. Brumbun and multicolours

\begin{tabular}{lcc}
\hline \multicolumn{1}{c}{ Semantic Features } & SL & TL \\
\cline { 2 - 3 } & Brumbun & Multicolours \\
\hline Abstract concept & + & + \\
All colours & - & + \\
It has sacred sense/ nuance & + & - \\
\hline
\end{tabular}

The word multicolours becomes the translation of the word brumbun. Based on the Oxford Advanced Learner's Dictionary, the word multicolours refers to the consisting of or decorated with many colors, especially bright ones. Thus, the English translation seen in the table captures the basic meaning of the composite of many colors, but the kinds of colors (red, 
black, yellow and white) are not associated in TL. It is needed to make clear that the composite of the color in brumbun does not mean the color becomes one. Brumbun, in this case the color of chicken's fur means the chicken has four colors (red, black, yellow and white) in its fur. The other gist carries by brumbun is also the sacred sense. Meanwhile, multicolours only represents the difference among the colors, the difference color of brumbun brings the essential of the harmony in word.

The next concept of Balinese cultural colour is putih siyungan. Putih is equal into white in English. Yet, when the word putih is added by siyungan, the meaning depicts a slightly different reference. Putih siyungan refers to the animal especially chicken whose fur is white, but the feet's colour is yellowish. The translator tends to translate putih siyungan into whitish black which still carry the basic meaning of the colour white. The translation only partially captures the meaning in SL. It is in line with the definition cited by Bell from Dictionary of Language and Linguistics (Hartmann \& Stork, 1972) which stated that "text in different languages can be equivalent in different degrees (fully or partially equivalent) in respect of different levels of presentation (equivalent in respect of context of semantic, of grammar, of lexis, etc.) and at different ranks (word-for-word, phrase-forphrase, sentence-for-sentence)."

SL: ... menggunakan lima ekor ayam dengan warna bulu yang berbeda, yaitu hitam, putih, merah jambu, brumbun, dan putih siyungan. (p.45)

TL: ... employs five chickens of different colours, namely black, white, crimson, multicolours and whitish black. (p.109)

Table 8. Putih siyungan and whitish black

\begin{tabular}{lcc}
\hline \multicolumn{1}{c}{ Semantic Features } & SL & TL \\
\hline Abstract concept & Putih Siyungan & Whitish Black \\
White colour & + & + \\
It refers to the colour of another's body part & + & + \\
\hline
\end{tabular}

The second cultural concept is related into the name of day. As a religious society, Balinese Hinduisms have many specific names of day depending on the specific story lied up with it. In this study, one of those is analysed as follow:

SL: Biasanya mereka memilih hari yang khusus untuk melakukan meditasi seperti misalnya kajeng kliwon, purnama, tilem atau pada hari sakral Nyepi. (p.58)

TL: Usually they choose a special day for medication such as magic day, full moon, new moon or sacred day of Nyepi. (p.116)

Kajeng kliwon is one of the day in which Balinese Hinduism will come to temple in order to pray. In this day, Balinese Hinduisms believe that one of the three main Deva, Shiva does meditation. This day comes every 15 days based on common calendar.

On the other hand, in society, there is another superstition of this day. Kajeng kliwon day becomes scared day since it is believed that in this day, people who have spirit (black magic) will 'send' their black magic to target. As a result, some parents do not allow their children to go out at dusk because they believe of those surrounded black magic in the environment at that day. In addition, in the past, kajeng kliwon day was believed as a day to neutralize some illnesses, such as goitre and rush caused by black magic.

Table 9. Kajeng Kliwon and magic day

\begin{tabular}{lcc}
\hline \multicolumn{1}{c}{ Semantic Features } & SL & TL \\
\hline Abstract concept & Kajeng Kliwon & Magic Day \\
It refers to specific day in religious concept & + & + \\
It comes every 15 days & + & - \\
Sacred day & + & - \\
\hline
\end{tabular}

The noun phrase kajeng kliwon is translated into magic day in TL. Western culture in the past might familiar with the occurrence of magic term. In sophisticated era, western culture seems unfamiliar with the term magic. They refuses the existence of magic because there is no scientific evidence of magic. Magic literally means the secret power of appearing to make impossible things happen by saying special words or doing special things. Related into this context, magic 
day may refer to the day when people who have spirit expel their spirit to make others get trouble. By looking at this definition, the translation of kajeng kliwon into magic day has reached the equivalence in term of its sense. However, even there is a word magic in TL, the readers especially western may not have the same 'sense' in their culture. It is as a result of the incredulity of magic in western culture. They may not receive or experience the same scared nuance. This case implies there is no obviously one to one equivalent in translating culture (Newmark, 1988).
Next data, the ultimate concepts of cultures are sekala and niskala worlds. Those two words belong to the Balinese Hinduisms belief as the world where we live and 'others', unseen creatures live as well. Sekala world points to the real world in common where we live, whereas niskala refers to the world where 'devil' and other unseen creatures live.

SL: Binatang seperti misalnya ayam, itik, babi, sapi dan kerbau mempunyai arti khusus, baik di dunia sekala atau di dunia niskala. (p. 49)

TL: Animals like chickens, ducks, pigs, cows and buffalos have a specific meaning, either in visible world or invisible world. (p.108)

Table 10. Sekala and visible world

\begin{tabular}{lcc}
\hline \multicolumn{1}{c}{ Semantic Features } & SL & TL \\
\cline { 2 - 3 } & Sekala & Visible World \\
\hline Inanimate & + & + \\
It is where we live in & + & + \\
\hline
\end{tabular}

In the data, the word sekala is translated into visible world. If it is analysed through the semantic features as stated above, it can be concluded that there is no gap between the SL and TL. It looks similar in meaning of SL and TL, but when the target readers, especially western people, read it, there will be a slightly strange sense in the word visible. The word world is clearly enough to refer to the world where we live in. It seems like an ambiguity in the phrase visible world. Hence, it can be said that in this case, the translator tends to denote the different world between the 'seen' and 'unseen' one. That is by seeing the context of situation in which the comparing is needed in order to convey clear understanding of the text.

In concert to compare the componential analysis of the previous data, the data below is presented:

SL: Binatang seperti misalnya ayam, itik, babi, sapi dan kerbau mempunyai arti khusus, baik di dunia sekala atau di dunia niskala. (p. 49)

TL: Animals like chickens, ducks, pigs, cows and buffalos have a specific meaning, either in visible world or invisible world. (p.108)

Table 11. Niskala and invisible world

\begin{tabular}{lccc}
\hline \multicolumn{1}{c}{ Semantic Features } & SL & TL \\
\cline { 2 - 4 } & Niskala & Invisible World \\
\hline Inanimate & + & + \\
It is where 'unseen creatures' & + & $+/-$ \\
including manifestation of God & & \\
and Devil live in & & \\
\hline
\end{tabular}

As referring to the explanation of previous data (data in Table 10), niskala is a concept of world where unseen creatures including the manifestation of God and devil live in. It does not merely refer to the world that cannot be seen by normal eyes, but it refers to world where there is life which is as similar as with humans' life. In Balinese belief, in the niskala world, there are many kinds of unseen creatures (familiarly with ghost in common people). They live in niskala world like having daily life in our world. The word niskala translated into invisible world has same degree of equivalence as in SL. This abstract concept may not or rarely occur in TL.
Thus, the translation of niskala into invisible world is clearly enough to be understood in TL. This example makes the evidence of statement "There is no exactly one-for-one correspondence from one language to another language."

The last cultural term is related into organization. The word banjar belongs to cultural term related into organization since banjar is one of the assemblies of members in one village. It means that banjar is a part of a village which has its authority to manage its society specifically in term of religious activity. Actually, banjar has two references. Those are a reference of Balinese Hinduism assemblies member and a place in 
which the meeting the assemblies member takes place. In this context, the word banjar refers to the assemblies' member of Balinese Hinduism. It can be seen as follow:

SL: Seperti pada hampir semua aspek kehidupan orang Bali, desa adat dan juga banjarnya diatur oleh adat... (p.15)

TL: As in almost all other spheres of Balinese life, the traditional village and also its neighbourhoods are regulated by adat... (p.80)
The translation of banjar as neighbourhoods seems slightly different in meaning in TL. As stated on the Oxford Advanced Learner's Dictionary, the word neighbourhood refers to a district or an area of a town where the people live there. However, in this context, the SL requires the main gist of banjar as a group or Balinese Hinduism assemblies' member.

Table 12. Banjar and neighbourhoods

\begin{tabular}{lcc}
\hline \multicolumn{1}{c}{ Semantic Features } & SL & TL \\
\hline Inanimate/thing & Banjar & Neighbourhoods \\
Abstract object & + & $+/-$ \\
Organization/ Group of people & + & $+/-$ \\
It has rules in managing the life of community & + & - \\
\hline
\end{tabular}

\section{Social culture}

The term of social culture occurs as a part of the occupation or job in the data in accordance with Newmark's (1988) categorization on the culture. The SL is balian which is translated into shaman. The data is as follows:

SL: Pada zaman dahulu, aktivitas tersebut dilakukan oleh sulinggih/pedanda, pemangku, balian dan mereka yang diinspirasi oleh literature. (p.57)

TL: In ancient times, this activity was indulged in by high priest, village priest, shaman and those who were inspired by literature. (p.116)

Balian depicts the meaning of a person who can cure the patients with magic illness in their body. Balinese Hinduisms are known as its belief to the spirit that cannot be seen. One spirit believed is a spirit to make others in dangerous condition especially in health aspect. In order to heal the illness caused by this invisible spirit, the occurrence of balian becomes the solution.

The ability had by balian can be got by studying some ancient Balinese manuscripts. However, in some cases, this ability is given to selected people. Those who are believed by God are given this ability without any learning process. It usually happens in one generation to the next. In this condition, she/he must use her/ his ability to help others. If she/he refuses to do this, she/he will get some troubles, such as getting sick without any medical reasons or passed away suddenly. Moreover, Balinese Hinduism priest sometimes can be a balian.

Table 13. Balian and shaman

\begin{tabular}{lcc}
\hline \multicolumn{1}{c}{ Semantic Features } & SL & TL \\
\hline Type of work & Balian & Shaman \\
She/ he has the ability to cure illness & + & + \\
through invisible magic spirit & + & + \\
Only done by selected people & & + \\
She/ he is a part of Hinduism priest & $+/-$ & - \\
\hline
\end{tabular}

By looking at the translation of balian above, shaman has partially conveyed the meaning of balian. Shaman is a person in some religions and societies who is believed to be able to contact good and evil spirits and cure people of illnesses based on Oxford Advanced Learner's Dictionary. The gap of balian and shaman merely is seen on the semantic feature as a part of priest or not. In western culture, shaman has no any relation as a priest of one religion. Despite missing one semantic feature, the backbone of a person who cure illness people from magic condition has been fulfilled.

\section{CONCLUSION}

In accordance with the aforementioned discussion, it can be concluded that there are some of Balinese cultural terms found which belong to Ecology; Material Culture; Organization, Customs, Activities, Procedures and Concepts; and Social Culture. In discussing the degree of translation equivalent of Balinese cultural terms into English, the applying of 
componential analysis has been showed some semantic features which leads to the information of loss and gain features available in target language. The attempt of translating culture terms may face difficulty to the translator. However, in this occasion, the translator has gained the appropriate term into TL in which it can be stated that the degree of equivalence match in some level depending on the cultural terms. This study may inspire translator to add more explication when facing the cultural terms in translation as result clear notion of SL can be provided. In addition, further research needs to be attempted in concert to enrich the explanation on the translation of Balinese culture.

\section{REFERENCES}

Cohen, M. F. (1985). Reality, language, translation: What makes translation possible. Paper presented in the American Translators Association Conference, Miami.

Hapsari, N. D., \& Setyaningsih, R. W. (2013). Cultural words and the translation in twilight. Anglicist, 2(2), 75-81. Retrieved from http://journal.unair.ac.id/download-fullpapersanglicistd056474059full.pdf.
Hartmann, R., \& Stork, F. (1972). Dictionary of language and linguistics. Amsterdam: Applied Science.

Kuncara, S. (2015). Cultural terms translation in Hirata's Laskar Pelangi and the impact on the translation quality. Journal of Culture, Arts, Literature, and Linguistics (CALLs), 1(1), 1-17. doi: 10.30872/calls.v1i1.705.

Larson, M. L. (1998). Meaning-based translation: A guide to cross-language equivalence ( $2^{\text {nd }}$ ed.). New York-Oxford: University Press of America.

Newmark, P. (1988). A textbook of translation. New York: Prentice Hall.

Rand, A. (1966). Introduction to objectivist epistemology. The Objectivist Inc.

Saraswati, R. (2014). The translation strategies in translating Balinese cultural words into English. Journal of English Language and Culture, 4(2), 110-119. Retrieved from https://journal.ubm.ac.id/index.php/englishlanguage-culture/article/view/323.

Wirayanti, N. K. R., Erfiani, N. M. D., \& Agustia, K. T. S. (2018). The procedure of translation in translating cultural term on Bali Travel News. Jurnal Litera Bahasa dan Sastra, 2(2), 1-12. Retrieved from https://jurnal.undhirabali.ac.id/index.php/lentera/ article/view/591. 